\title{
ANALYTICAL APPLICATION OF THE REACTION SYSTEM ALIZARINE-HYDROGEN PEROXIDE IN BORATE BUFFER MEDIA FOR THE SPECTROPHOTOMETRIC KINETIC DETERMINATION OF Ni(II)
}

Sofija M. Rančić1 ${ }^{*}$, Snežana D. Nikolić-Mandić , Aleksandar Lj. Bojić1 ${ }^{1}$, Snežana M. Đorić-Veljkovićc ${ }^{3}$ Aleksandra R. Zarubica ${ }^{1}$, Predrag Lj.Janković ${ }^{4}$

(ORIGINAL SCIENTIFIC PAPER)

UDC 546.742:543.48

${ }^{1}$ Department of Chemistry, Faculty of Science and Mathematics, University of Niš, Serbia

2Faculty of Chemistry, University of Belgrade, Serbia

${ }^{3}$ Faculty of Civil Engineering and Architecture, University of Niš, Serbia

${ }^{4}$ Faculty of Mechanical Engineering, University of Niš, Serbia

A rapid, simple, sensitive and selective new spectrophotometric kinetic method for $\mathrm{Ni}(\mathrm{II})$ traces determination at room temperature was elaborated in this paper. It is based on the catalytic effect of nickel ions upon the oxidation of alizarine $(A L)$ by hydrogen peroxide in borate buffer (BUF) solution. The method was confirmed by determination of $\mathrm{Ni}(\mathrm{II})$ traces in fresh water samples. The obtained results were compared to those obtained by ICP-OES method and good agreement of the results was found.
Keywords: Ni(II) determination, catalyst, spectrophotometric kinetic method

\section{Introduction}

No doubt, nickel is one of the most interesting heavy metals today. It is abundant in lithosphere and biosphere so that natural deficiency does not occur. Nickel is an important alloying element for steel and cast iron. It is incorporated in electrodes, coins, ships, magnets, turbines, etc. Because of its permanence in air, nickel is also adequate for iron and brass plating. It is an essential trace element and micro nutrient in humans, as well as in number of animals and plants: nearly $40 \mathrm{ng} / \mathrm{ml}$ of $\mathrm{Ni}(\mathrm{II})$ is required for normal metabolism of many living organisms. Normal human plasma contains about 0.012 to $0.085 \mathrm{ppm}$ of $\mathrm{Ni}(\mathrm{II})$. Nickel is the cofactor of some biologically important enzymes and when bound to ribonucleic acid it has a special affinity to bones and skin and plays a significant role in pigmentation. On the other hand, higher amounts of nickel, both in the form of inorganic salts and some soluble organic complexes are well known as carcinogens of living organisms and serious environmental pollutants: nickel can bind to the cell membrane and hinder the transport process through the cell wall. So, the development of new methods for Ni(II) determination is of continuing scientific interest and it is also very important for the better eco systems monitoring in future.

There are different published methods for $\mathrm{Ni}(\mathrm{II})$ determination. Atomic absorption spectrometry (AAS) methods, like flame (FAAS) [1-3], electrothermal (ET AAS) [4], high resolution continuum source graphite furnace (HR-CS GF AAS) with a previous extraction from the original matrix) [5] are very interesting. Also, inductively coupled plasma (ICP) methods like ICP-MS $[6,7]$ and ICP-OES $[8,9]$ are in expansion. Various classes of organic reagents, especially hydrazones, have been described as spectrophotometric reagents for $\mathrm{Ni}(\mathrm{II})$ determination [10-13]. After the cloud-point extraction and preconcentration procedure, the authors determined nickel as the complex with 2-amino-cyclopentene-1-dithiocarboxylic acid (ACDA), using Triton-X-114 as surfactant [10]. Saritha and Sreenivasuly Reddy formed the green complex of $\mathrm{Ni}(\mathrm{II})$ and 5-bromo-2-hydroxyl-3-methoxybenzaldehide-4-hydroxy benzoic hydrazone with the absorption maximum at $440 \mathrm{~nm}$ [11], while other Indian authors built the nickel complex with pyridine 2,3 dicarboxylic acid [12].

Laser induced breakdown spectroscopy (LIBS) [14]; Xray fluorescence techniques [15] and spectro-fluorimetric method [16] for nickel traces determination are also reported.

Nickel was determined in different samples like meteorites [14], soils [5,17,18,19], garnets [9], alloys [11], a dry skin membrane and larva slough of some animals which are used as medicines [8], in plants and vegetable oil [11], bean seed [1], food [2], canned tomato paste [4], biological materials, human serum, urine and hair [6,15], alcoholic beverages $[7,5]$, drinking water $[2,3,10,11,13]$, sea, rain, marine, fresh and ground water $[2,14,20,21]$, synthetic samples [12], etc.

\section{Experimental}

\section{Apparatus}

Spectrophotometric measurements were performed on UV-VIS spectrophotometer Shimadzu UV- VIS 1650 PC (Shimadzu, Japan). ICP-OES measurements were

\footnotetext{
*Author address: Sofija Rančić Department of Chemistry, Faculty of Science and Mathematics, University of Niš, Višegradska 33, 18000 Niš, Serbia

E-mail: sofija_rancic@yahoo.com

The manuscript received: June, 19, 2015

Paper accepted: September, 14, 2015
} 
performed on ICP-OES, model ICAP 65000 Duo (Thermo Scientific, UK). Cylindrical cells were thermostated at $20.00 \pm 0.02{ }^{\circ} \mathrm{C}$ using thermo-circulating bath (Julabo MP$5 \mathrm{~A}$ ). $\mathrm{pH}$ measurements were performed using a Hach H260G pH-meter with a non-glass $\mathrm{pH}$ probe $\mathrm{PH} 77 \mathrm{SS}$ (Hach, USA).

\section{Reagents and Chemicals}

Analytical grade reagents provided by Merck, Germany, unless indicated otherwise, and ultrapure water (18.2 M 2 ) (water purification system Thermo Fisher Scientific Smart 2 Pure Standard) were utilized for the preparation of the solutions. Adequate polyethylene vessels were used for storage of the solutions. Borate buffer solutions were prepared by mixing the sodium tetraborate solution with $\mathrm{HCl}$ and $\mathrm{NaOH}$ solutions according to the rule, and their $\mathrm{pH}$ values were checked using a $\mathrm{pH}$-meter. A stock $\mathrm{Ni}(\mathrm{II})$ solution $\left(1 \cdot 10^{-4} \mathrm{~g} \mathrm{~cm}^{-3}\right)$ was prepared by dissolving the exactly measured $\mathrm{NiCl}_{2} \cdot 6 \mathrm{H}_{2} \mathrm{O}$ in deionized water. The concentration of the stock solution was checked complexometrically. The alizarine solution $\left(0.002 \mathrm{~mol} \mathrm{dm}^{-3}\right)$ was prepared by dissolving the exactly measured substance in $\mathrm{NaOH}$ solution $\left(0.1 \mathrm{~mol} \mathrm{dm}^{-3}\right)$. This solution was stable for five days. All polyethylene containers and the glassware were washed with diluted hydrochloric acid (1:1), the solution of potassium hydroxide in ethanol and then repeatedly well rinsed by tap water, distilled and deionised water. All concentrations described here are the initial concentrations in the reaction mixture at time zero after mixing. Each kinetic result is the average of five determinations.

\section{Procedure}

In order to obtain good mechanical and thermal stability, the instruments were run for ten minutes before the first measurement. Selected volumes of reactants and deionized water were poured separately in the reaction mixture vessel with four compartments (Budarin vessel) up to a predeterminated total volume of $10 \mathrm{~cm}^{3}$. The solution of $\mathrm{Ni}(\mathrm{II})$ was measured into one leg of the Budarin vessel for catalytic reaction and the same volume of deionized water was measured for non-catalytic reaction. After thermo-stating for ten minutes, the reagents were mixed and simultaneously the stopwatch was turned on. The solution was immediately added to a properly rinsed spectrophotometer cell with a path length of $10 \mathrm{~cm}$, and the absorbance was measured every 15 seconds, starting from the 45th second of the reaction up to ten minutes of the reaction. Spectrophotometric measurements were performed at the wavelength of $460 \mathrm{~nm}$, and at working temperature of $20 \pm 0.02^{\circ} \mathrm{C}$.

The reaction was tested by examining the influence of each component of the reaction mixture upon the reaction rate of catalytic and non-catalytic reaction. The concentration of each component was changing consecutively, while the concentrations of other components, as well as the working temperature, were kept constant.

\section{Results and discussion}

While the reaction proceeds, the initial violet color of the solution fades and a pale yellow reaction product is formed. Neither the exact mechanism of the reaction nor the chemical nature of the products was of major interest in the investigation. Spectrophotometric measurements were performed at the wavelength of the absorption maximum of alizarine $(460 \mathrm{~nm})$ in borate buffer media (Figure 1). The logarithm of absorbance-time curves is linear during the first five to ten minutes of the reaction for different $\mathrm{Ni}(\mathrm{II})$ concentrations, so all kinetic results were treated by the integral variant of the tangent method [22]. The rate of the reaction was obtained using the slope of the kinetic curves of the absorbance - time plot.

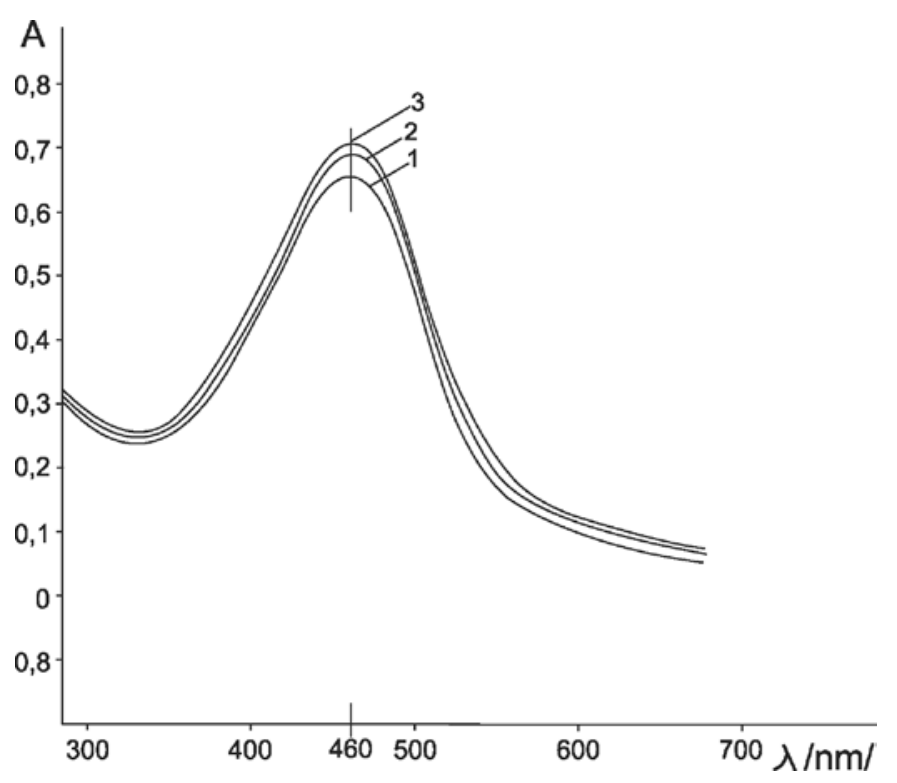

Figure 1. Absorption spectra of alizarine in borate buffer. Initial conditions: $\mathrm{AL} 8.0 \cdot 10^{-5} \mathrm{~mol} \mathrm{dm}^{-3} ; 20 \pm 0.02{ }^{\circ} \mathrm{C}$; $\mathrm{pH}$ : 1 - 10.6; 2- $9.1 ; 3-8.5$

Hence, the influence of the $\mathrm{pH}$ value of the selected borate buffer solutions on the rate of both the catalytic and non-catalytic reactions was examined in the $\mathrm{pH}$ interval of about 7.7 to about 9.0 (Figure 2). The value of 8.46 was selected as the most appropriate one, because it provides difference of the reaction rates of the catalytic and non-catalytic reactions and good reproducibility of absorbance measurements in the absorbance area of the least error for spectrophotometric measurements, for both reactions very well. The same principles were used for the selection of optimal conditions in all further investigations. The borate buffer $\mathrm{pH} 8.46$ was used in subsequent examinations.

The rates of both the catalytic and non-catalytic reaction show the first order dependence on the buffer concentration (Figure 3 ) within the range of $5.2 \cdot 10^{-3}$ to $7.8 \cdot 10^{-3} \mathrm{~mol} \mathrm{dm}^{-3}$, and the concentration of $6.5 \cdot 10^{-3} \mathrm{~mol}$ $\mathrm{dm}^{-3}$ was selected as the optimal concentration of the borate buffer for further measurements. 


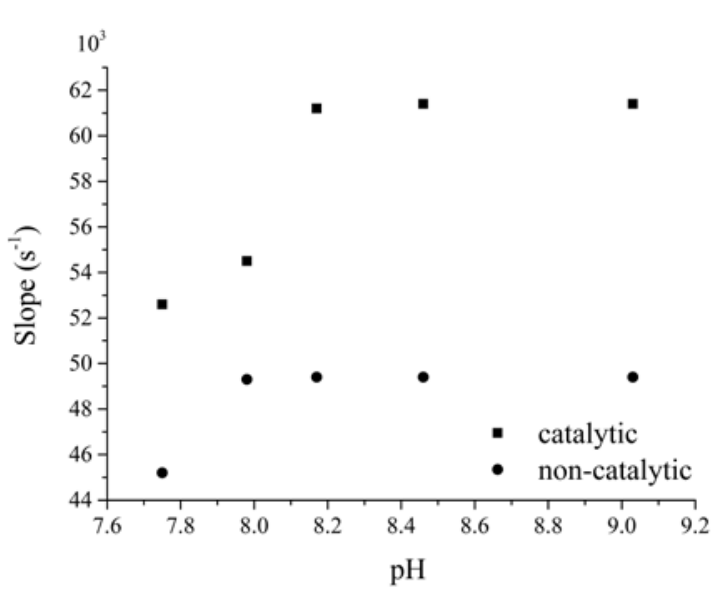

Figure 2. Dependence of the reaction rate on $\mathrm{pH}$. Initial con-

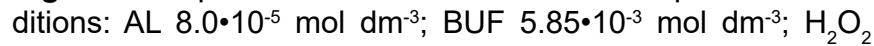
$0.2 \cdot 10^{-3} \mathrm{~mol} \mathrm{dm}^{-3}$; $\mathrm{Ni}(\mathrm{II}) 4.0 \mu \mathrm{g} \mathrm{cm}{ }^{-3} ; 20 \pm 0.02{ }^{\circ} \mathrm{C}$. A-catalytic reaction, B-non-catalytic reaction.

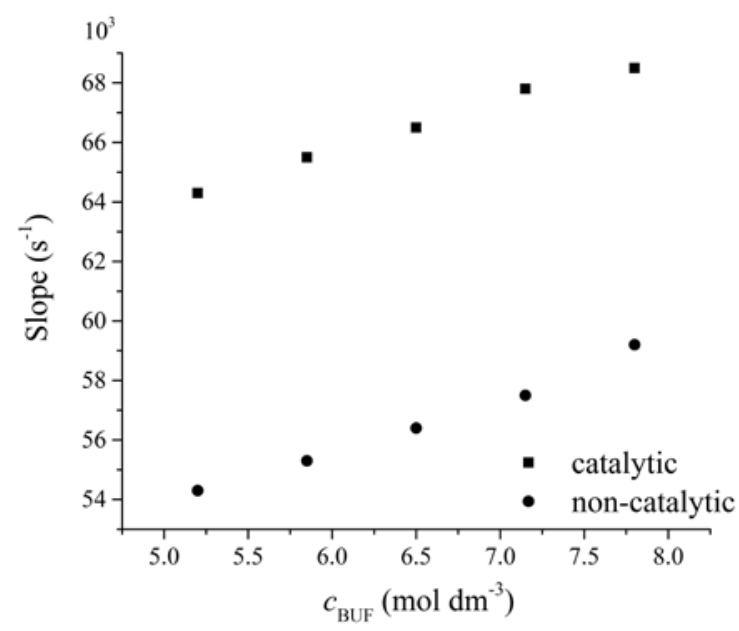

Figure 3. Dependence of the reaction rate on the BUF concentration. Initial conditions: $\mathrm{pH} 8.46 ; \mathrm{AL} 8.0 \cdot 10^{-5} \mathrm{~mol} \mathrm{dm}^{-3} ; \mathrm{H}_{2} \mathrm{O}_{2}$ $0.2 \cdot 10^{-3} \mathrm{~mol} \mathrm{dm}^{-3}$; $\mathrm{Ni}(\mathrm{II}) 4.0 \mu \mathrm{g} \mathrm{cm}^{-3} ; 20 \pm 0.02{ }^{\circ} \mathrm{C}$. A-catalytic reaction, $\mathrm{B}-$ non-catalytic reaction.

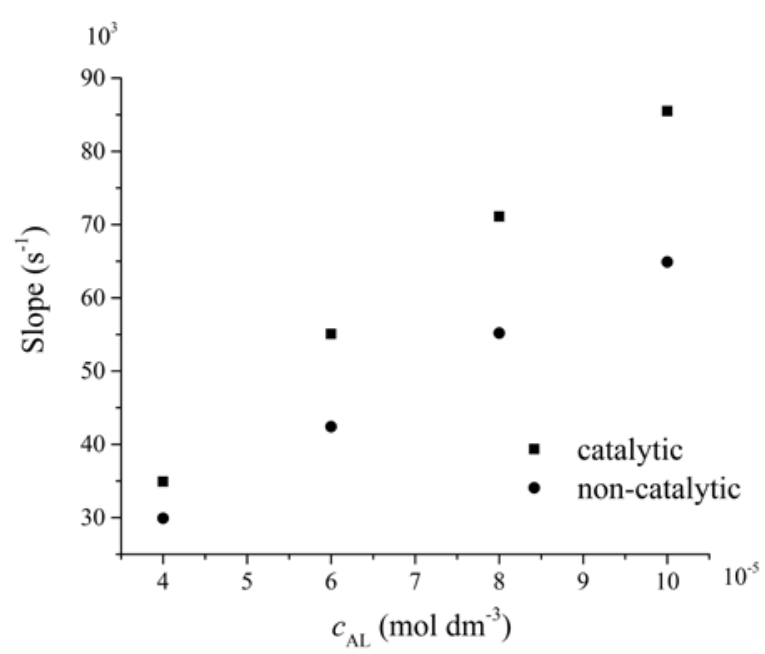

Figure 4. Dependence of the reaction rate on the $A L$ concentration. Initial conditions: $\mathrm{pH}$ 8.46; BUF $6.5 \cdot 10^{-3} \mathrm{~mol} \mathrm{dm}^{-3} ; \mathrm{H}_{2} \mathrm{O}_{2}$ $0.2 \cdot 10^{-3} \mathrm{~mol} \mathrm{dm}^{-3}$; Ni(II) $4.0 \mu \mathrm{g} \mathrm{cm}^{-3} ; 20 \pm 0.02{ }^{\circ} \mathrm{C}$. A-catalytic reaction, B-non-catalytic reaction.
The dependence of the rate of the catalytic and noncatalytic reactions on the reducing agent concentration was monitored within the concentration range of $4.0 \cdot 10^{-5}$ to $10.0 \cdot 10^{-5} \mathrm{~mol} \mathrm{dm}^{-3} \mathrm{AL}$. Within this interval, both catalytic and non-catalytic reaction rates show a first order dependence of the AL concentration (Figure 4). The concentration of $8.0 \cdot 10^{-5} \mathrm{~mol} \mathrm{dm}^{-3} \mathrm{AL}$ was selected as optimal.

At last, the influence of the concentration of the oxidant was tested (Figure 5). Within the investigated concentration range of $\mathrm{H}_{2} \mathrm{O}_{2}$ of $0.2 \cdot 10^{-3}$ to $0.8 \cdot 10^{-3} \mathrm{~mol} \mathrm{dm}^{-3}$, both catalytic and non-catalytic reaction rates show a first order dependence of the oxidant concentration. $\mathrm{H}_{2} \mathrm{O}_{2}$ concentration of $0.4 \cdot 10^{-3} \mathrm{~mol} \mathrm{dm}^{-3}$ was selected as adequate for further work because it provides a good difference of the reaction rates of catalytic and non-catalytic reactions.

Hence, the optimal conditions were found to be: $\mathrm{pH}$ 8.46, $\mathrm{cBUF}=6.5 \cdot 10^{-3} \mathrm{~mol} \mathrm{dm}^{-3}, \mathrm{cAL}=8.0 \cdot 10^{-5} \mathrm{~mol} \mathrm{dm}^{-3}$, $\mathrm{CH}_{2} \mathrm{O}_{2}=0.4 \cdot 10^{-3} \mathrm{~mol} \mathrm{dm}^{-3}$.

Under the optimal conditions, the dependence of the catalytic reaction rate on the $\mathrm{Ni}(\mathrm{II})$ concentration was observed at three temperatures: $20 \pm 0.02,23 \pm 0.02$ and $25 \pm 0.02{ }^{\circ} \mathrm{C}$. The linear dependence of calibration curves falls within the range of $7.0 \cdot 10^{-7}$ to $8.0 \cdot 10^{-6} \mathrm{~g} \mathrm{~cm}^{-3} \mathrm{Ni}(\mathrm{II})$.

The adequate equations of calibration curves for $20 \pm 0.02{ }^{\circ} \mathrm{C}$ (Eq. 1), $23 \pm 0.02{ }^{\circ} \mathrm{C}$ (Eq. 2), and $25 \pm 0.02{ }^{\circ} \mathrm{C}$ (Eq. 3), were calculated as follows:

$$
\begin{aligned}
& \text { Slope }=(0.01027 \pm 0.00001) \cdot c+(0.01495 \pm 0.00017) \ldots \ldots .(1) \\
& \text { Slope }=(0.01234 \pm 0.00003) \cdot c+(0.01811 \pm 0.00015) \ldots \ldots .(2) \\
& \text { Slope }=(0.01325 \pm 0.00002) \cdot c+(0.02246 \pm 0.00011) \ldots \ldots .(3)
\end{aligned}
$$

where: $\mathrm{c}$ is $\mathrm{Ni}(\mathrm{II})$ concentration in $\mu \mathrm{g} \mathrm{cm}^{-3}$.

The accuracy and precision of the method were checked for three different $\mathrm{Ni}(\mathrm{II})$ concentrations within the range of the calibration curve. Five repeated measurements were performed for each concentration. Satisfactory results were obtained. For $\mathrm{Ni}(\mathrm{II})$ concentrations of $5.0 \cdot 10^{-6} \mathrm{~g} \mathrm{~cm}^{-3}, 6.0 \cdot 10^{-6} \mathrm{~g} \mathrm{~cm}^{-3}$ and $7.0 \cdot 10^{-6} \mathrm{~g} \mathrm{~cm}^{-3}$, RSD values were found to be $4.6 \%, 3.2 \%$, and $2.7 \%$, respectively.

The selectivity of the method was established by interference studies: selected ions were separately added in the reaction mixture. The tolerance limit was estimated as the concentration of the added ion that gives up to a $3 \%$ relative error in the determination of nickel. Cations were added as chlorides or nitrates and anions were added as sodium or potassium salts. Each ion was added in six known concentration ratios (0.01:1, $0.1: 1,1: 1,10: 1,100: 1$ and 1000:1) against the constant $\mathrm{Ni}(\mathrm{II})$ concentration of $1.0 \mu \mathrm{g} \mathrm{cm}^{-3}$. The measurements were performed at $20 \pm 0.02{ }^{\circ} \mathrm{C}$, and about 30 most frequently used cations and anions were tested $\left(\mathrm{Na}^{+}, \mathrm{Ag}^{+}\right.$, $\mathrm{Ca}^{2+}, \mathrm{Sr}^{2+}, \mathrm{Ba}^{2+}, \mathrm{Mg}^{2+}, \mathrm{Zn}^{2+}, \mathrm{Cu}^{2+}, \mathrm{Pb}^{2+}, \mathrm{Pd}^{2+}, \mathrm{Co}^{2+}, \mathrm{Hg}^{2+}$, $\mathrm{Sn}^{2+}, \mathrm{Bi}^{3+}, \mathrm{Fe}^{3+}, \mathrm{Al}^{3+}, \mathrm{As}^{3+}, \mathrm{Sb}^{3+}, \mathrm{Au}^{3+}$, acetates, tartarates, 
oxalates, molybdates, wolframates, $\mathrm{Br}, \mathrm{I}^{-}, \mathrm{NO}^{-}, \mathrm{SO}_{4}{ }^{2-}$, $\left.\mathrm{CO}_{3}{ }^{2-}, \mathrm{PO}_{4}{ }^{3-}\right)$. The results presented in Table 1 reveal that proposed methods for nickel determination have a very good selectivity.

Table 1. Selected results of interference studies for nickel determination, initial conditions: $\mathrm{pH} 8.46 ; \mathrm{AL} 8.0 \cdot 10^{-5} \mathrm{~mol} \mathrm{dm}^{-3}$; BUF $6.5 \cdot 10^{-3} \mathrm{~mol} \mathrm{dm}^{-3} ; \mathrm{H}_{2} \mathrm{O}_{2} 0.4 \cdot 10^{-3} \mathrm{~mol} \mathrm{dm}^{-3} ; \mathrm{Ni}(\mathrm{II}) 1.0 \mu \mathrm{g}$ $\mathrm{cm}^{-3} ; 20 \pm 0.02{ }^{\circ} \mathrm{C}$

\begin{tabular}{ccc}
\hline Added ion & Ion ratio:Ni(II) & Nickel determination \\
\hline $\mathrm{Co}(\mathrm{II})$ & 1000 & catalyzes \\
$\mathrm{Pb}(\mathrm{II})$ & 1000 & inhibits \\
$\mathrm{Hg}(\mathrm{II})$ & 100 & catalyzes \\
\hline
\end{tabular}

Only the presence of $\mathrm{Co}^{2+}$, in the ratio $1000: 1$, and $\mathrm{Hg}^{2+}$, in the ratio 100:1 against the nickel concentration, catalyzes the determination of nickel, while the presence of $\mathrm{Pb}^{2+}$, in the ratio $1000: 1$, inhibits the determination of nickel by the proposed method. The ions that interfere the determination of nickel can be easily removed by standard analytical methods like masking, precipitation, etc., depending of different samples nature.

By application of spectrophotometric technique, at the wavelength of $460 \mathrm{~nm}$, a limit of quantification (LQ) of $119 \mathrm{ng} \mathrm{cm}^{-3} \mathrm{Ni}(\mathrm{II})$ was reached, and the limit of detection (LD) of $31 \mathrm{ng} \mathrm{cm}^{-3} \mathrm{Ni}(\mathrm{II})$ was obtained. LQ was defined as the ratio signal : noise $=10: 1$ and LD was defined as signal 3:1 against the blank.

The method was successfully applied to $\mathrm{Ni}$ (II) determination in fresh water samples. The samples were analyzed by application of both, the presented spectrophotometric kinetic method and ICP-OES method. As presented in Table 2, there is a good agreement of the results.

Table 2. $\mathrm{Ni}(\mathrm{II})$ determination in fresh water samples, initial conditions: $\mathrm{pH} 8.46$; $\mathrm{AL} 8.0 \cdot 10^{-5} \mathrm{~mol} \mathrm{dm}^{-3}$; BUF $6.5 \cdot 10^{-3} \mathrm{~mol} \mathrm{dm}^{-3}$; $\mathrm{H}_{2} \mathrm{O}_{2} 0.4 \cdot 10^{-3} \mathrm{~mol} \mathrm{dm}^{-3} ; 20 \pm 0.02{ }^{\circ} \mathrm{C}$

\begin{tabular}{|c|c|c|c|c|}
\hline Sample & $\begin{array}{c}\text { Spectrophotometric- } \\
\text { kinetic } \\
\text { determination }^{\mathrm{a}}\end{array}$ & $\begin{array}{c}\text { Recovery } \\
\%\end{array}$ & $\begin{array}{l}\text { Determination } \\
\text { by ICP-OES }\end{array}$ & $\begin{array}{c}\text { Recovery } \\
\%\end{array}$ \\
\hline & $\mu \mathrm{g} \mathrm{cm}-3$ & & $\mu \mathrm{g} \mathrm{cm}^{-3}$ & \\
\hline 1 & $3.84 \pm 0.04$ & 95.1 & $3.99 \pm 0.02$ & 99.8 \\
\hline 2 & $3.97 \pm 0.06$ & 96.4 & $4.12 \pm 0.02$ & 99.6 \\
\hline 3 & $5.85 \pm 0.03$ & 97.3 & $5.98 \pm 0.02$ & 99.8 \\
\hline 4 & $5.97 \pm 0.02$ & 97.7 & $6.25 \pm 0.02$ & 99.7 \\
\hline
\end{tabular}

aThe mean value of five measurements $\pm 2 \mathrm{SD}$

\section{Conclusions}

The proposed spectrophotometric kinetic method for the determination of $\mathrm{Ni}(\mathrm{II})$ shows a very good selectivity and provides a rapid and easy performance at room temperature $\left(20^{\circ} \mathrm{C}\right)$ by using available equipment and cheap chemical substances. The obtained results are precise and reproducible. The RSD value was found to be in the range $2.7-4.6 \%$ for the investigated concentration range of $\mathrm{Ni}(\mathrm{II})$.

On the grounds of the obtained results, the new spectrophotometric kinetic method is recommendable for the determination of $\mathrm{Ni}(\mathrm{II})$ in fresh water samples and potentially also in other samples from the industrial processes and the environment. The results suggest that it could also be a good basis for further investigations of spectrophotometric kinetic methods for the heavy metals trace analysis.

\section{References}

[1] M. Khajeh, N. Sarafi, FAAS method for determination of $\mathrm{Ni}, \mathrm{Zn}, \mathrm{Cu}, \mathrm{Fe}, \mathrm{Mn}$ and $\mathrm{Co}$ in bean seed samples with microwave assisted extraction method, Ind. J. 14 (5) (2014) 194-200.

[2] C. Duran, S.O. Tumay, D. Ozdes, H. Serencam, H. Bektas, Simultaneous separation and preconcentration of $\mathrm{Ni}(\mathrm{II})$ and $\mathrm{Cu}(\mathrm{II})$ ion by coprecipitation without any carrier element in some food and water samples, Int. J. Food Sci. Tech. 49 (2014) 1586-1592.

[3] J.L. Manzoori, G. Karim-Nezhad, Development of a cloud-point extraction and preconcentration method for $\mathrm{Cd}$ and Ni prior to flame atomic absorption spectrometric determination, Anal. Chim. Acta 521 (2004) 173-177.

[4] K.G. Raptopoulou, I.N. Pasias, N.S. Thomaidis, C Proestos, Study of the migration phenomena of specific metals in canned tomato paste before and after opening Validation of a new quality indicator for open cans, Food Chem. Tox. 69 (2014) 25-31.

[5] W. Boschetti, A.R. Borges, A.T. Duarte, M.B. Dessuy, M. Goreti, R. Vale, J.B. de Andrade, B. Welz, Simultaneous determination of $\mathrm{Mo}$ and $\mathrm{Ni}$ in wine and soil amendments by HR-CS GF AAS, Anal. Methods 6 (2014) 4247-4256.

[6] M. Badran, A. Ismail, R. Morsy, T. Elnimr, Critical evaluation for five digestion methods using ICP-MS, J. Pharm. Sci. Innov. 3 (1) (2014) 30-34.

[7] D.P.C. de Quadros, D.L.G. Borges, Direct analysis of alcoholic beverages for the determination of cobalt, nickel and tellurium by inductively coupled plasma mass spectrometry following photochemical vapor generation, Microchem. J. 116 (2014) 244-248.

[8] L.Yang, Y.Li, G.Xj., X.Ma, Q.Yan, Comparison of dry ashing, wet ashing andmicrowave digestion for determination of trace elements in periostracum serpentis and periostracum cicadae by ICP-AES, J. Chil. Chem. Soc. 58 (3) (2013) 1876-1879.

[9] K.S. Viljoen, J.W. Harris, T. Ivanić, S.H. Richardson, K. Gray, Trace element chemistry of peridottic garnets in diamonds from Premier (Cullinan) and Finsch kimberlites, South Africa: contrasting styles of mantle metasomatism, Lihtos (2014), doi;10.1016/j.lihtos.2014.08.010.

[10] A. Safavi, H. Abdollahi, M.R. Hormozi-Nezhad, A. Kamali, Cloud point extraction, preconcentration and simultaneous spectrophotometric determination of nickel and cobalt in water samples, Spectrochim. Acta, Part A 60 (2004) 2897 2901.

[11] B. Saritha, T. Sreenivasuly Reddy, Direct spectrophotometric determination of $\mathrm{Ni}$ (II) using 5-bromo2-hydroxyl-3-metoxybenzaldehide-4-hydroxy benzoic hydrazine, IOSR J. App. Chem. 7, 3 (2014) 22-26.

[12] C.S. Jayprakash, P.V. Ajit, Synthesis, characterization and spectrophotometric determination of $\mathrm{Ni}(\mathrm{II})$ ion by pyridine 2,3 dicarboxylic acid, Int. Res. J. Pharm. App. Sci. 3 (5) (2013) 31-36.

[13] A. Moghimi, Extraction of $\mathrm{Ni}(\mathrm{II})$ on microcrystalline naphthalene modified with organic-solution-processable 
functionalized nano graphene, Russ. J. Phys. Chem. Part A 88, 7 (2014) 1177-1183.

[14] M. Dell Aglio, A. De Giacomo, R. Gaudiuso, O. De Pascale, S. Longo, Laser induced breakdown spectroscopy of meteorites as a probe of the early solar system, Spectrochim. Acta, Part B 101 (2014) 68-75.

[15] U.Majewska, D.Banas, J.Braziewicz, A.Kubala-Kukus, M.Pajek, I.Sychowska, J.Wudarzyk-Mocko, G.Antczak, B.Borkowska, S.Gozdz, X-ray fluorescence techniques in medical applications: reference values of elements in human serum, urine and hair, Acta Phys. Pol., Part A 125, 4 (2014) 864-868.

[16] K. Kargosha, M.S. Maleki, J. Azad, Spectrofluorimetric determination of $\mathrm{Ni}(\mathrm{II})$ with murexide, J. Fluoresc. 24 (2014) 855-858.

[17] S. Likuku, K.B. Mmolawa, G.K. Gaboutloeloe, Assessment of heavy metal enrichment and degree of contamination around the copper-nickel mine in the Selebi Phikwe region, eastern Botswana, Envir. Ecol. Res. 1 (2) (2013) 32-40.

[18] H. Jaworska, A. Bartkowiak, S. Rozanski, The influence of antropogenically increased $\mathrm{pH}$ on the content and the mobility of nickel in arable soils in the surroundings of "Malogoszcz" cement plant, Soil Sci. Ann. 64 (1) (2013) 14-18.

[19] S.X.Quan, B.Yan, F.Yang, N.Li, X.M.Xiao, J.M.Fu, Spatial distribution of heavy metal contamination in soils near a primitive e-waste recycling site, Environ. Sci. Pollut. Res., doi. 10.1007/s11356-014-3420-8.

[20] R.M. Izatt, K. Pawlak, J,S. Bradshaw, R.L. Bruening, Thermodynamic and kinetic data for macrocycle interaction with cations, anions and neutral molecules, Chem. Rev. 95 (1995) 2529-2586.

[21] V. Ghoulipour, S.W. Husain, Inorganic ion-exchangers for quantitative TLC of toxic elements. $V$ separation anndetermination of chromium(VI), Acta Chromatogr. 12 (2002) 170-177.

[22] D. Perez-Bendito, M. Silva, Kinetic methods in analytical chemistry, Ellis Horwood Ltd, Chichester, 1998.

\section{Izvod}

\section{PRIMENA REAKCIONOG SISTEMA ALIZARIN-H $\mathrm{O}_{2} \mathrm{O}$ BORATNOM PUFERU ZA SPEKTROFOTOMETRIJSKO KINETIČKO ODREĐIVANJE NIKLA}

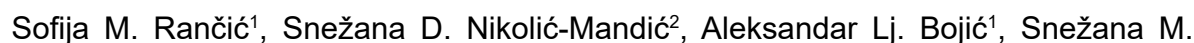
Đorić-Veljković ${ }^{3}$, Aleksandra R. Zarubica ${ }^{1}$, Predrag Lj. Janković ${ }^{4}$

${ }^{1}$ Departman za Hemiju, Prirodno-matematički fakultet, Univerzitet u Nišu, Srbija

2 Hemijski fakultet, Univerzitet u Beogradu, Srbija

3 Građevinsko-arhitektonski fakultet, Univerzitet u Nišu, Srbija

4 Mašinski fakultet, Univerzitet u Nišu, Srbija

Predložena spektrofotometrijska kinetička metoda za određivanje Ni(II) pokazuje vrlo dobru selektivnost i lako se i brzo izvodi na sobnoj temperaturi $\left(20^{\circ} \mathrm{C}\right)$. Uz korišćenje dostupne opreme i jeftinih supstanci, postižu se precizni i reproduktivni rezultati. Spektrofotometrijskim merenjem, na talasnoj dužini od $460 \mathrm{~nm}$, postignuta je granica kvantifikacije (LQ) od $119 \mathrm{ng} \mathrm{cm}^{-3} \mathrm{Ni}(\mathrm{II})$, kao i granica detekcije (LD) od $31 \mathrm{ng} \mathrm{cm}^{-3} \mathrm{Ni}(\mathrm{II})$. LQ je definisana kao odnos signal : šum = 10:1 and LD kao signal $3: 1$ u odnosu na slepu probu. RSD vrednosti se nalaze u rasponu od $2,7-4,6 \%$ za ispitivanu oblast koncentracija $\mathrm{Ni}(\mathrm{II})$. Na osnovu dobijenih rezultata se može zaključiti, da je nova kinetička spektrofotometrijsko metoda pogodna za određivanje $\mathrm{Ni}(\mathrm{II})$ u prirodnim vodama, a potencijalno i u drugim uzorcima iz proizvodnih procesa i životne sredine. Takođe, rezuItati ispitivanja ukazuju na to da ona može da bude dobra osnova za dalja istraživanja u oblasti razvoja novih spektrofotometrijskih kinetičkih metoda za analizu teških metala.
(ORIGINALNI NAUČNI RAD)

UDK 546.742:543.48

Ključne reči: određivanje $\mathrm{Ni}(\mathrm{II})$, katalizator, spektrofotometrijska kinetička metoda 